\title{
Predictors and Risk Factors of Armed Robbery Victimisation in Nigeria: An Integrated Theoretical Perspective
}

\author{
Etuk, Grace Reuben (PhD) \\ Department of Social Work, Faculty of Social Sciences, \\ University of Calabar, Calabar, Nigeria \\ Macpherson U. Nnam (M.Sc.)
}

Department of Criminology and Security Studies, Faculty of Management and Social Sciences, Alex Ekwueme Federal University, Ndufu-Alike, Ikwo, Ebonyi State, Nigeria

\section{Doi:10.19044/esj.2018.v14n29p1 URL:http://dx.doi.org/10.19044/esj.2018.v14n29p1}

\begin{abstract}
The rapidly increasing rate of armed robbery victimisation in Nigeria necessitated the integration of five relevant victimological and sociological/criminological theories in this paper to provide a detailed account of the causal processes and conditions that predict this offending behaviour. The paper is essentially theoretical, relying mainly on library research and review of relevant literature to obtain necessary data and information. It was found that armed robbery, as a social problem, is caused by many factors and the associated risk factors are countless and destructive. Issues raised suggest a policy direction that will ensure a timely and objective incorporation of the global best practices - as enshrined in the Victims' Bill of Right (VBR), among others, into the Nigerian legal system, so as to effectively combat armed robbery victimisation and related offences. The official introduction of victim impact statements, victim-offender reconciliation, crisis interventions and restorative justice into the Nigerian criminal justice system is also advocated for. Additionally, it is suggested that social service agencies and/or providers should extend their caring services beyond victims of disaster/disease and terrorism to include armed robbery victims, given the alarming nature and extent of this phenomenon in the country.
\end{abstract}

Keywords: Armed Robbery, Integrated Theoretical Perspective, Predictors, Risk Factors, Victimisation. 


\section{Introduction}

Traditionally, sociologists, criminologists and criminal justice administrators were primarily concerned with the investigation of crime incidents and crime perpetrators. However, adequate attention was not accorded to the role, whether passive or active, played by victims during crime transactions. This was why the emergence of victimology, a branch of criminology, as an independent academic discipline in the early 40s rekindled the curiosity and need for a more balanced and objective discourse on predictors, as well as risk factors of criminal victimisation (Alemika, 2011). Even the nominal founder of victimology, Hans Von Hentig, acknowledged this in his victim-complicity hypothesis in which he pointed out that there is a frequently observed real mutuality in the connection of perpetrator and victim, killer and killed, as well as duper and duped (Von Hentig, 1940). In line with this, Siegel (2008) observed that previously, Criminologists laid more emphasis on the actions of the criminal offender, while basically ignoring the role of the victim; adding that in the last 60 years or thereabout, scholars started coming to terms with the fact that crime victims are not always mere passive targets in crime, but ones whose behaviours function to determine their fate in the event of crime.

Following the establishment of modern victimology, two schools of thought have emerged. In the views of Alemika (2011), on one side are those who believe "victims' actions, as well as behaviours, could expose them to victimisation or make them attractive to predators" while those on the other side of the argument focus on their similarities in terms of socioeconomic and demographic milieu. Alemika (2011) took particular note that since the early 1960 s, and particularly the 1980s, victims' movements surfaced to solicit policy responses to victimisation. Indeed, this has provoked deep thoughts and interdisciplinary scholarship (i. e. Sociology marrying Criminology), policy reactions and development, as well as social movements that focused on understanding victim-offender relationships and reactions of the society and criminal justice system to criminal victimisation. Attention has also been devoted to victim or victimisation studies, with particular emphasis on the dire need to provide forward-looking interventions for the protection of and care for crime victims in the real world.

The issue of criminal victimisation in its general form is complex and unwieldy, requiring researchers to narrow their interests to a particular crime victim or criminal victimisation. It then follows that delimiting the complex problem of victimisation to a specific crime is necessary to keep any study in perspective. In view of this, coupled with the increasing incidence of armed robbery in Nigeria, this paper attempts to build a strong integrated framework for explaining the phenomenon of armed robbery, with a view to achieving the following objectives: 
- formulate an all-encompassing theoretical framework for understanding the predictors of armed robbery victimisation;

- identify the risk factors of armed robbery victimisation; and

- determine how victims of armed robbery can be protected and/or cared for.

\section{The Phenomenon of Armed Robbery}

The problem of armed robbery is fast growing, cutting across cultures and social classes, with many lives and property (victims) destroyed. Thus, Otu and Elechi (2015) acknowledged that in a bid to address the continuous rise in armed robbery incidences in Nigeria, many criminologists have become relentless in searching for plausible explanations for this type of criminal behaviour. It is frequently linked either to individual traits or wide socioeconomic variables such as deprivation in terms of unemployment or joblessness, low income or outright poverty as well as family destabilisation.

All societies, whether developed or developing, are currently facing escalated rates of armed robbery victimisation. In 2005, the United States Federal Bureau of Investigation (FBI), recorded about 420, 000 armed robberies, a rate greater than $140 \%$ per 100,000 population (Siegel, 2008). Also in 2011, the FBI reported further that in the United States, over \$30 million was stolen, and about 100 people killed or injured in 5,000 armed robberies of financial organisations (mainly banks); while 447,403 robbery cases were reported to the police, resulting in a rate of 'one per minute' (Oputeh, 2015). In Nigeria, the situation of things is no different. The country is also facing heinous offending behaviour of different typologies, among which is soaring rates of armed robbery victimisation. Studies and evidential data reveal that armed robbery is among the top three most serious crimes in Nigeria. For instance, the Nigeria Police Annual Report (NPAR) indicated that a total of 2,704 armed robbery offenses were reported in 2005; 2, 863 in 2006; 2,327 in 2007 and 2, 340 in 2008 (NPAR, 2006, $2007 \&$ 2008). The National Bureau of Statistics Report (NBSR) in 2008 revealed that of the 36 states of the federation, Kano, Ogun, Oyo, Delta and Cross River States, were the worst affected with grave armed robbery incidents (NBSR, 2008; Otu, \& Elechi, 2015). Furthermore, a look at the summarised statistics of armed robbery victimisation in the country as presented by the Centre for Law Enforcement Education in Nigeria (CLEEN) shows that the trend has been that of a steady rise from $11 \%$ in 2010 to $17 \%$ in 2012 (CLEEN, 2012). The understanding from the foregoing is that robbery or armed robbery is a global problem with many victims. Indeed, as Otu and Elechi (2015) stressed, the crime of armed robbery is on the increase, affecting all classes of people who may have directly or indirectly experienced victimisation in the process. 


\section{Predictors of Armed Robbery Victimisation: An Integrated Theoretical Perspective}

The processes and conditions that predict armed robbery victimisation follow a complex pathway, which can best be understood and explained using an integrated theoretical perspective. For this reason, five relevant victimology and sociology/criminology theories are systematically integrated to address the core of the problem. The use of integrated theoretical approach to the study of crime; according to Beirne and Messerschmidt (2000), remains the pathway through which both criminology and sociology are looking forward to be as simple and as common as possible. As a justification for adopting this approach, this paper alluded to Lanier and Henry's (2004) argument that an integrated perspective is required to analyse the sequential chain of events, especially when a crime (such as armed robbery victimisation) is an outcome of several different causes. Lanier and Henry (2004) argued further, that the purpose of integrating theories is to present an interaction of probabilities from different theoretical perspectives that could explain the factors contributing to a person committing a crime.

To maintain the central concern of this paper, the integration of Lifestyle-Exposure, Routine Activity, Deviant Place, Opportunity and Cognitive Maps Theories becomes necessary. Meier and Miethe (1993) considered the integration of Routine Activity and Lifestyle-Exposure Theories as necessary to account for the importance of geographical closeness as a form of motivation for offenders, exposure to high risk environments, target attractiveness, as well as absence of (capable) guardianship as necessary conditions for predatory crimes (such as armed robbery). The predictions of lifestyle-exposure and routine activity perspectives are dovetailing in that people increase their risk of or inadvertently expose themselves to armed robbery victimisation for several reasons. Examples include residing in a deviant/criminal neighbourhood (viz: slums, shanties and ghettos) and flashpoint areas where people of the minority origin and lower social backgrounds are living (this supports deviant place model). Carrying expensive portable items such as laptops, smartphones, expensive articles of jewellery and large sums of money in crime-prone areas without capable guardians or hardening the targets (the said items) also predisposes individuals to armed robbery attacks.

Also deduced from the basic tenets of Deviant Place, Routine Activities and Lifestyle-Exposure perspectives is the fact that involvement of individuals in risky behaviour and lifestyle, as well as morally and socially reprehensible acts, such as those of street urchins may give rise to victimisation. Associated with these predisposing factors, as implicated in the assumptions of these theories, are indecent dressing, illegal gambling, attending night club and orgies, and abusing psychoactive substances. For instance, students or young 
individuals who 'keep routine' (frequently patronise a particular pub or visit a particular place for relaxation) that has weak or total absence of security network, and are also engaged in excessive and binge drinking remain prime targets for armed robbery and other predatory crimes. Still on the LifestyleExposure, as well as Routine Activity approaches to the understanding of the causal factors of armed robbery victimisation, research shows that youths join gangs (secret cults) and adopt a career of using, abusing as well as distributing illegal drugs, while committing property and violent crimes (Zhang, Welte, \& Wieczorek, 1999). Members of criminal subcultures or gangs, especially campus and street secret cults almost always indulge in 'crime-switch'changing from cultism (secret cult activities) to substance abuse, rape, kidnapping and armed robbery - or interchanging or switching these offences over time to beat security. Although gang or cult violence is indicative of nuances of the struggle for supremacy among different cult groups, the fact should not be vitiated that armed robbery victimisation is also a characteristic of cultists (Nnam, 2014).

Klo"tz, Peterson, Isacson and Thiblin (2007) revealed that many violent crimes such as armed robbery committed by youths were linked with the lifestyle of drug addicts. It includes violence perpetrated to sponsor expensive drug abuse, and violence that has to do with aggressive patterns of interaction that occur in connection with the use of drug as well as distribution (that is, punishment for not being able to pay one's drug-associated debts or violent disagreements between drug dealers over territories, and drug paraphernalia). Most armed robbers usually plan their activities and celebrate their offending behaviour and exploits in pubs and secluded places where they use and abuse psychoactive substances, particularly marijuana and high-powered alcoholic drinks. This behaviour may predispose them to victimisation or increase their chances of victimising others. Linking substance abuse to victimisation, Jensen and Brownfield (1986) noted that young people use a great deal of time to hang out with friends, as well as pursue recreational entertainment. They usually go around in taverns at night, which puts them at risk, since many fights, as well as assaults, occur in places where liquor is served.

Substance abusers, besides often being victimised themselves, tend to commit more crimes, including armed robbery than non-abusers (Zhang et al., 1999; Klo "tz et al., 2007). Building on the National Institute on Drug Abuse report in the United States, Fletcher and Chandler (2014) opined that drug culture is linked to offences directly related to drug abuse, namely, robbing to get money for drugs. Also, many armed robbers use drugs or alcohol close to the time they commit crime, which increases their chances of leaving behind a number of victims and casualties. Iwarimie-Jaja (2003) explained that most armed robbers in Nigeria use and abuse drugs, particularly marijuana before and after carrying out their criminal activities. Admittedly, armed robbers are 
not only habitual victimisers but also extroverts, hedonists and chronic womanisers, who patronise isolated and hidden taverns, 'weed bunks' (isolated places where marijuana and other psychoactive substances are smoked and taken at will), rendezvous and fraternity houses. Arguably, most armed robbery operations and victimisations are usually planned and/or executed in these locations.

Following this are Opportunity and Cognitive Maps Theories which are a corollary of socio-spatial criminology - a paradigm shift from individual to neighbourhood characteristics as predictors of armed robbery victimisation. Scholars suggest that "Opportunity and Cognitive Maps Theories are distinct but have often been not only combined, but also have been frequently employed in policing circles and victimisation studies (Haralambos, Holborn, \& Heald, 2008). Cognitive map is a social x-ray, atlas and compass reading that guide criminals or victimisers in their victimisation career. The assumptions of this model are that people, usually criminals/victimisers draw and carry different maps of the areas they live in or visit regularly, with different motives. Most of them are conversant with their chosen targets, because their residences are not far from their targets. Cognitive maps provide insightful analysis of certain crimes, namely, armed robbery, burglary, kidnapping, stalking and unlawful spying. Offenders who specialise in these categories of offences rationally stake out the areas of their operational interest to reduce the chances of failure or arrest and increase their possibilities of success and easy escape.

Brantingham and Brantingham (1991) suggested that people are most likely to offend (i.e. rob or victimise others) when they are faced with opportunities in areas which are cognitively familiar to them, and they are far less expected to perpetrate crime within areas outside the cognitive maps (this supports routine activity and opportunity theories). Besides, Opportunity Theory presents itself as a suitable approach to explaining why and where offending (victimisation) occurs (Felson, \& Clark, 1998 cited in Haralambos et al., 2008). Like other theories of victimisation, Opportunity Theory explains how, where and why accessible, attractive and suitable targets are attacked. By way of illustration, 'suitable targets' (both human and material) are prone to attacks when they are not properly hardened or where capable guardians (policing agents, effective burglar proof and alarm, proactive neighbourhood watch and other crime discouragers) of such targets are absent or weak.

Opportunity Theory explains why most robberies and burglaries are most likely to take place in houses that contain visible attractive and valuable 'easy-to-carry' (portable) goods and services, when house-owners have gone out for their routine activities - place of work, business, school and church. Crime/victimisation equally occurs in houses that are located in isolated and physically/socially disorganised neighbourhoods with inadequate security (this 
supports deviance place and routine activity theories). Available literature reveals that the more people are exposed to dangerous places (deviant/criminal neighbourhoods), the more they likely become victims of crime as well as violence (Rechards, Larso, \& Miller, 2004). Similar tendency or fate awaits individuals whose routine activities place them at high risk of falling victim to criminals who are motivated by opportunities to victimise others. This is where Cognitive Maps, Routine Activities and Opportunity Theories coalesce with Deviant Place Theory, although Lifestyle and Exposure Theories disagree on that score. Garofalo (1987) claimed that crime victims are not (always) responsible for their attacks, except victim-prone ones since they live in socially jumbled and offence-prone neighbourhoods, which put them at risk of coming in contact with (motivated) criminals. This condition exposes them to criminal victimisation, regardless of their behaviour or habit.

Furthermore, neighbourhood crime level can be a very crucial factor than individual characteristics or lifestyles for determining the chances of (armed robbery) victimisation (Siegel, 2008). Deviant environments are usually poor, thickly inhabited, and highly transient where commercial and residential property exist side by side (Stark, 1987). Such an environment places residents at a high risk of robbery victimisation; and provides victimisers with suitable targets and easy escape. Offenders engage in certain crimes such as pickpocketing, shoplifting and assaults in this type of environment. Residents of such defenceless and unsecure backgrounds may not only be susceptible to armed robbery victimisation, but also are predisposed to other criminal victimisations such as assault and battery, kidnapping, rape and related sexual offences, and even violent death. Giddens (2006) pointed out that individuals living in inner city areas (i.e. 'deviant places') face a larger risk of being victims of crime, than inhabitants of more wealthy sub-urban districts; adding that disproportionate concentration of ethnic minorities at the inner city areas seems to be an important factor in the higher rates of criminal victimisation.

\section{Risk Factors of Armed Robbery Victimisation}

The impact of armed robbery victimisation is usually severe and longterm. Victims of armed robbery might be gravely injured, and their belongings nastily damaged by their assailants. The hardship experiences encountered by victims include a wide variety of losses, injuries/wounds, and deprivations. The immediate, direct or primary victims of armed robbery and vicarious victims (people living in a victim's household, community, or their relatives and friends) sometimes suffer the same or similar fate. Directly or indirectly, they suffer numerous pains ranging from the economic, social, psychological/emotional, medical and monetary to death, resulting from armed robbery. Siegel (2008) noted that, as the cost of goods (and services) obtained 
through crimes were added to productivity losses caused by injury, and pain as well as emotional trauma, the cost of victimisation was projected to hundreds of billions of dollars. Besides, fear of re-victimisation and its associated trauma are serious psychological problems experienced by crime victims and even their relatives. To some scholars, namely Rountree (1998) and Acierno, Rheingold, Resnick and Kilpatrick(2004), a number of crime victims, the elderly in particular, poor as well as minority group members, develop constant and paralysing fear of being victimised again. They continue to be fearful even long after their injuries had healed. Additionally, individuals who escaped the assaults could develop fears, as well as become timid and careful, after hearing of another person's victimisation.

The most obvious effect of armed robbery victimisation, although, trailing behind death, is 'defencive injuries'. These are severe injuries sustained by victims at the time of attack, which occur in their attempt to escape or disarm their victimisers. Defencive injuries are spontaneously sustained since victims struggle to subdue offenders or grasp their weapon. Also, it can be inflicted by any offender on account of premeditation; that is, intentionally imposed to lessen the likelihood of victims' to resist or escape. The nature and extent of defencive wounds are essential, determined by the kind of weapons, as well as the force used for assault, and level of resistance put up by the victim. According to Gunn (2009) and Brown and Muscari (2010), defencive injuries are frequently seen on the hands, as well as forearms, which victims raise to defend the head and face or ward off an assault. However, such injuries may also be found on feet and legs, and occurs when victims try to protect themselves while lying down. Injuries on feet and legs may also be as a result of victims attempting to kick at the assailant. In Nigeria, as in other countries of the world, defencive wounds are commonplace.

Arguably, victims of armed robbery may suffer additional victimisation in the hands of institutions detailed and authorised by the law and custom to assure public safety, victims' rights, as well as return justice when fundamental rights of the people are contravened. In Nigeria, as tenable in most parts of the world, victims are further victimised by agents in the criminal justice system. The Nigeria police and court systems in particular contribute to the burdens of armed robbery victims as evident in their systemic selective policing and adjudication. Corroborating this view, Alemika and Chukwuma (2000) affirmed that the poor are more liable to endure disproportionally for violating the same law, than the rich. The consciousness of this situation in Nigeria is vital, especially when there is a disparity between 'the rich, and the poor' in the police treatment patterns. Ordu and Nnam (2017) maintained that selective policing (and its resultant victimisation) is a common phenomenon in Nigeria. The police often conspire with organised criminals (i.e. disgruntled 
political leaders or highly placed public office holders) to exploit citizens and undermine their plight at will.

Even in the Western world, researchers and scholars of social problems, namely Hess, Markson and Stein (1992) attested that the affluent or political classes were not policed as the poor. The former often have a virtual monopoly in crime since it is in most instances connected with a gang (who continue to victimise the underprivileged using State agents of social control). Some victims experience economic hardships owing to wages lost as they undergo all court processes, and they may find that authorities are unconcerned about their fear of facing possible retaliation if they co-operate in the offender's prosecution (Finn, 1988). 'Survivors' (victims of rape for instance) have had their cases handled unprofessionally by the police during interrogation, with innuendoes and insinuations that they were somewhat at fault. Others complained that they received unimaginable inhuman treatments and services from the legal and health institutions (Campbell, \& Raja, 1999). Thus, the suffering endured by crime victims does not stop as their aggressor leaves the scene of the crime, as some of them suffer further victimisation by the justice system (Siegel, 2008). This scenario particularly applies to armed robbery incidents to the extent that there are usually unnecessary delays in terms of investigation and transmission of case files from the police to court for a celeritous trial. All of these put together compromise justice considering that 'justice delayed is justice denied'. Furthermore, some stolen but recovered items are often kept longer than necessary with police or courts as exhibits and evidence. In fact, sometimes, such items are not given back to the owners/victims when the matter is over.

\section{Combating Armed Robbery Victimisation/Caring for Victims of Armed Robbery}

The war on armed robbery victimisation and providing support for victims of armed robbery are the main responsibility of the entire society. Government, and non-governmental organisations, religious, law enforcement agencies, families, courts, rehabilitation homes, social workers, caregivers, educational institutions as well as human right advocates are deeply involved in the war. Safeguarding victims' rights to assistance as well as supports is the main concern of these agencies. Siegel (2008) asserted that a good number of crime victim programmes recommend victims to particular services, so as to assist them recuperate from their ordeal. Generally, clients are referred to a local network of public and private social service agencies, which give emergency and long-term help with transportation, medical care, as well as shelter, food, and clothes. Siegel added that a large number of crime victim programmes, give crisis intervention for victims who feel secluded, vulnerable as well as require immediate services. A number of victim intervention 
professionals carry out counselling in offices, while the rest visit crime casualties at home, the scene of crime, hospital and others.

One reliable strategy for combating armed robbery victimisation is through target hardening, which Garofalo (1987) described as a technique of controlling criminal activities, (including armed robbery victimisation) by fortifying areas that could be seen as targets in order to increase the risks that will be encountered by offenders (victimisers). This anti-victimisation measure is mostly needed in socially disorganised and high-risk neighbourhoods where offending and victimisation are uncontrolled. The idea of target hardening is to make it extra difficult for crimes (or victimisations) to occur (Giddens, 2006). As a powerful anti-robbery strategy, target hardening emphasises the dire need to install modern burglar proof and alarm, Closed Circuit Television (CCTV), Crime Mapping Technology (CMP), automobile steering locks, and vehicle tracking devices.

Another insightful way of addressing armed robbery victimisation and caring for victims as suggested by Siegel (2008) - even though it is currently not obtainable in Nigeria - is through the adoption of Victim-Offender Reconciliation Programme (V.O.R.P). Siegel (2008) succinctly defined VORP as a mediated face-to-face encounter between victims and assailants, intended to bring about restitution, agreement, and possibly, reconciliation. Closely related to this approach is Restorative Justice, which Nnam (2016) defined as a victim-offender community-centred justice intervention, devoid of noncustodian procedures of balancing the scale of justice made uneven by crime as well as criminals. Nnam added that to restore justice amounts to reinstituting sanity, mutual understanding, as well as peaceful coexistence after separation, conflict, victimisation, and incidence of crime.

In addition, with the restorative justice system in place, the social harm individuals or the community experience, threatened security and property lost, are to a significant extent restored (Nnam, 2016). Other scholars believe that restorative justice is praised, appreciated and recommended for facilitators or mediators in the society due to its strengths in reconciling victims with their criminals to the position they were at before the attack, and this reconciliation is community-based and non-custodian (Braithwaite, 1998, 2002; Levrant, Cullen, Fulton, \& Wozniak, 1999). Restorative Justice is yet to be officially incorporated into the criminal justice system; but it is utilised in the informal setting in mending fences between victims and their offenders, as well as in reuniting them with the community. Because of its encompassing advantages in solving victimisation problem in both ancient and modern societies, the position of Zehr (2002) when he suggested a universal adoption and application of restorative justice measures for effective prevention and control of criminal victimisation becomes particularly relevant. Even though restorative justice is frequently not easy to define as it includes various 
programmes and practices; Zehr (2002) added that this phenomenon requires society to address victims' damages and needs, hold criminals answerable to correct those damages, as well as engage victims, offenders and communities in the healing procedure.

Victim Impact Statements (VIS) is another robust intervention for protecting victims of armed robbery. This programme provides social supports as well as judicial pleasure to crime victims and relations, as vicarious casualties. The concept of VIS offers a chance in addition to uninhibited settings for crime victims to state their awful experiences, as well as habitual terrible ordeal in the hands of their attackers through legal proceedings.

\section{Conclusion}

From the foregoing, it is clear that socially and physically disorganised neighbourhoods are usually crime-breeding grounds and crime-prone; and therefore susceptible to armed robbery attacks. People take advantage of both victimogenic and criminogenic characteristics of such surroundings to rob one another. Vulnerability to armed robbery attacks is even increased because targets in such areas are often not hardened due to the fact that such areas are usually deteriorated, socially and morally so polluted that offending now seems to be more or less a norm rather than a crime. Exposure to violence and availability of crime-encouragers viz: ostensible lifestyle as regards displaying portable and expensive items in crime-prone areas without adequate security, are strong predictors of armed robbery attacks. Residents of such neighbourhoods are naturally poor and socially excluded. To overcome their plight in terms of joblessness, poverty and low income, coupled with dysfunctional security network, crimes of different typologies become inevitable as an escape route. Also, in such localities, to state the obvious, social control, both formal and informal is usually weak, thus putting the lower classe who are the foremost residents of such communities at greater risks of falling prey to armed robbers.

In addition to deviant neighborhoods as deciding factors of armed robbery victimisation, it is established that criminal exposure and lifestyle of persons incline them to victimisation by others. The risk of armed robbery victimisation is thus enlarged by victims' way of life as often expressed in obscene and provoking dressing by young girls, who are members of cult group or sub-cultural gang with boys; hanging out in pubs late in the night; and selling as well as abusing psychoactive substances, and the like. It follows that some victims of armed robbery are relatively the architect of their own misfortune. However, this must not vitiate the fact that social and demographic characteristics such as age, gender, race or ethnic background and social class of persons can directly or indirectly influence their attacks. 
Without a doubt, armed robbery victimisation is increasing and has substantial long-term negative effects, not only on a victim (immediate victims), but also on relatives and society in general (vicarious victims). Risk factors associated with this offending behaviour are psychologically and socially debilitating. The resultant pains are excruciating and cause financial hardship and economic loss, such as damage and plunder of property. Victims are further abused by the system detailed to assist them. The scale of justice no longer weighs even, as the rule of law, supremacy of the law, fundamental human rights and equality before the law have been compromised, eroded and supplanted by selective policing and justice delivery at the expense of the downtrodden and lower class people in society, who lack the resources to seek and obtain both impartial social and legal justices when they are victimised.

\section{Policy Implications}

From the review, regrettably, there is a paucity of concrete and practical crime victim programmes in Nigeria compared to what is acceptable in the Western world in terms of global best practices. Unfortunately still, the few accessible ones are scarce to several victims, particularly victims of armed robbery. On the basis of this, the government, together with additional groups such as the National Emergency Management Agency (NEMA), Social Workers, Nigerian Red Cross Society and other humanitarian organisations should extend selfless and caring services further to victims of tragedy, disease and internally displaced persons to include or cover crime victims, particularly victims of armed robbery. The Legal Aid Council of Nigeria (LACN) and other probono service providers such as Civil Society Groups (CSG), as well as Human Rights Activists (HRA) should make stronger efforts in giving crisis intervention and services to indigent crime victims standing trial in court. Public and private social service organisations should likewise give both emergency and long-term assistance by way of economic and financial compensation, public enlightenment on victimisation, medical care and legal aid to armed robbery victims.

It is of great essence to urgently incorporate the 'Victims' Bill of Right' (VBR) into the Nigerian legal system, for a successful war on armed robbery victimisation. The Bill emphasises, among other things, the participation and contribution of victims during court proceedings, and restitution by a convicted offender. Victims' advice should be sought and obtained prior to a plea bargaining or the dismissal of cases, and their contact information must be kept confidential to guard against repeat victimisation or re-victimisation. Based on its success in controlling predatory crimes such as armed robbery in both developing and developed nations, it is strongly recommended that VBR be introduced into the Nigerian legal system as a remedy for the complex problem of armed robbery victimisation. 
Lastly, and very importantly, it is suggested in very strong terms that Victim Impact Statements (VIS), Victim-Offender Reconciliation Programmes (VORP), crisis intervention, victim compensation, as well as restorative justice be institutionalised in the Nigerian legal system, as practical measures for combating armed robbery victimisation.

\section{References:}

1. Acierno, O., Rheingold, A., Resnick, H., \& Kilpatrick, D. (2004). Predictors of fear of crime in old adults. Journal of Anxiety Disorders, 18, 385-396.

2. Alemika, E. E. O., \& Chukwuma, I. C. (2000). Police-community violence in Nigeria. Lagos: Centre for Law Enforcement Education and National Human Rights Commission.

3. Alemika, E. E. O. (2011). Security, criminal justice and criminal victimisation in Nigeria. In E. E. O. Alemika, \& I. Chukwuma (Eds.), Crime victimisation, safety and policing in Nigeria (pp. 1-19). Lagos: Malthouse Press.

4. Beirne, P., \& Messerschmitt J. (2000). Criminology (3rd ed.). Boulder Colorado, London: Macmillan.

5. Braithwaite, J. (1998). The handbook of crime and punishment. In M. Tonry (Ed.), Restorative justice (pp. 323-344). New York: Oxford University Press.

6. Braithwaite, J. (2002). Restorative justice and responsive regulation. In J. Braithwaite (Ed.), Does restorative justice work? (pp. 45-71). New York: Oxford University Press.

7. Brantingham, P. J., \& Brantingham, P. L. (1991). Environmental criminology (rvd. ed.). $\quad$ Prospect Heights, IL: Waveland Press.

8. Brown, K. M., \& Muscari, M. E. (2010). Quick reference to adult and older adult forensics: A guide for nurses and other health care professionals. New York: Springer.

9. Campbell, R., \& Raja, S. (1999). Secondary victimisation of rape victims: Insights from mental health professionals who treat survivors of violence. Violence and Victims, 14, 261-274.

10. Centre for Law Enforcement Education in Nigeria. (2012). Summary of findings of 2012 national crime and safety survey. Retrieved from http://cleenfoundation.blogspot.com.ng/2012/07/summary-offindings-of-2012 Federal Bureau of Investigation. (2000). Crime in the United States. Retrieved from https://www.fbi.gov/aboutus/cjis/ucr/crime-in-the-u.s/2000/toc00.pdf

11. Finn, P. (1988). Victims. Washington, DC: US Department of Bureau of Justice Statistics. 
12. Fletcher, B. W., \& Chandler, R. K. (2014). Principles of drug abuse treatment for criminal justice populations: A research-based guide. National Institute on Drug Abuse: The Office of Science Policy and Communications.

13. Garofalo, J. (1987). Reassessing the lifestyle model of criminal victimisation. In M. Gottfredson\& T. Hirschi (Eds.), Positive criminology (pp. 23-42). Newbury, CA: Sage.

14. Giddens, A. (2006). Sociology (5th ed.). United Kingdom: Policy Press.

15. Gunn, A. (2009). Essential forensic biology. Chester: John Wiley \& Sons.

16. Haralambos, M., Holborn, M., \& Heals, R. (2008). Sociology: Themes and perspectives (7th ed.). London: HarperCollins.

17. Hess, B. B., Markson, E. W., \& Stein, P. J. (1992). Sociology (Brief ed.). New York: Macmillan Publishing.

18. Iwarimie-Jaja, D. (2003). Criminology: The study of crime (2nd ed.). Owerri: Springfield Publishers.

19. Jensen, G., \& Brownfield, D. (1986). Gender, lifestyles, and victimisation: Beyond routine activity theory. Violence and Victims, 14, 85-99.

20. Lanier, M., \& Henry, S. (2004). Essential criminology (2nd ed.). United States of America: Westview Publishers.

21. Levrant, S., Cullen, F. T., Fulton, B., \& Wozniak, J. F. (1999). Reconsidering restorative justice: The corruption of benevolence revisited? Crime and Delinquency, 45, 1-18.

22. Klo“tz, F., Petersson, A., Isacson, D.,\&Thiblin, I. (2007). Violent crime and substance abuse: A medico-legal comparison between deceased users of anabolic androgenic steroids and abusers of illicit drugs. Forensic Science International. Retrieved from http://www.doi:10.1016/j.forsciint.2007.01.026.

23. Meier, R. F., \& Miethe, T. D. (1993). Understanding the theories of criminal victimisation. Crime and Justice, 17, 459-499.

24. Miethe, T. D., \& Meier, R. F. (1994). Crime and its social context: Toward an integrative theory of offenders, victims, and situations. Albany, NY: State University of New York Press.

25. National Bureau of Statistics Report. (2008). National Bureau of Statistics Report. Abuja: Federal Government of Nigeria.

26. Nigeria Police Annual Report. (2006). The Nigeria Police Annual Report. Ikeja, Lagos "F" Department and Nigeria Police Printing Press, FHQ annex. 
27. Nigeria Police Annual Report. (2007). The Nigeria Police Annual Report. Ikeja, Lagos "F" Department and Nigeria Police Printing Press, FHQ annex.

28. Nigeria Police Annual Report. (2008). The Nigeria Police Annual Report. Ikeja, Lagos "F" Department and Nigeria Police Printing Press, FHQ annex.

29. Nnam, M. U. (2016). Responding to the problem of overcrowding in the Nigerian prison system through restorative justice: A challenge to the traditional criminal justice system. International journal of Criminal Justice Sciences, 11(2), 177-186.

30. Oputeh, M. (2015). Nigeria and the menace of armed robbery. Retrieved from https://www.today.ng/opinion/16020/nigeria-and-themenace-of-armed-robbery.

31. Ordu, G. E., \& Nnam, M. U. (2017). Community policing in Nigeria: A critical analysis of current developments. International Journal of Criminal Justice Sciences, 1(11), 83-97.

32. Otu, S. E., \& Elechi, O. E. (2015). Pathways and trajectories to lifecourse persistent armed robbery offending behaviour in contemporary Nigeria: Examining the predictors and the risks factors. International Journal of Criminal Justice Sciences, 10(1), 1031.

33. Rechards, M., Larso, R., \& Miller, B. (2004). Risky and predictive context and exposure to violence in urban African American young adolescents. Journal of Clinical Child and Adult Psychology, 33, 138148.

34. Rountree, P. W. (1998). A reexamination of the crime-fear linkage. Journal of Research in Crime and Delinquency, 35, 341-372.

35. Siegel, L. J. (2008). Criminology: The core (3rd ed.). Belmont, CA: Thomson Higher Education.

36. Stark, R. (1987). Deviant places: A theory of the ecology of crime. Criminology, 25, 893-911.

37. Von Hentig, H. (1940). Remarks on the interaction of perpetrators and victims. Journal of Criminal Law, Criminology and Police Science, 31, 303-309.

38. Zhang, L., Welte, J., \& Wieczorek, W. (1999). Youth gangs, drug use and delinquency. Journal of Criminal Justice, 27, 101-109.

39. Zehr, H. (2002).The little book of restorative justice.PA: Good Books Intercourse. 